\title{
INTRODUCTION: Transnationalism,
} diaspora and the migrationdevelopment nexus in Asia and Australia

Edition 8, 2021

Professor Andrew Rosser and Associate Professor Yan Tan

DOI: 10.37839/MAR2652-550X8.7

The number of people living outside their country of birth has increased dramatically in recent decades. In 1970, according to estimates produced by the United Nations Department of Economic and Social Affairs (UN DESA), there were 84 million people living abroad, representing 2.3 percent of the world's population. By 2020, these numbers had increased to 281 million and 3.6 percent respectively.

The past three decades have also witnessed a marked change in the nature of international migration. It is no longer dominated by singular movements from one country to another involving permanent settlement in the latter; rather, it is dominated by temporary and circular movements.

This growth in international migration and change in its nature are in large part the product of economic globalisation. Economic globalisation has entailed not only the transnationalisation of production and the globalisation of financial markets but also the 'tendential emergence of a global labor market'. At the same time, technological advances in transportation and communications have made it easier and less costly for people to travel and live across national borders. 


\section{Transnationalism, diaspora, and the migration-development nexus}

This context has stimulated renewed interest among scholars and policy-makers in the migration-development nexus.

Early studies of this topic operated within a paradigm of permanent migration and settlement and focused on the adjustment of immigrants to countries of destination, the economic impact of migration in destination countries, and 'brain drain' effects in countries of origin.

By contrast, more recent studies have frequently employed a transnational lens. Transnationalism focuses on the 'multiple ties and interactions linking people or institutions across the borders of nation-states' and their implications for development in origin and destination countries.

In particular, it is concerned with the nature and effects of economic linkages such as remittances and business networks, political linkages such as civil society networks and state policies on dual citizenship and voting rights, socio-cultural linkages such as those emanating from social, cultural and religious networks, familial linkages such as those between spouses and parents and children, and subjective linkages such as those produced by a sense of belonging to a homeland.

More recent studies have also tended to utilise the notion of diaspora. This notion originally referred to 'people who were forced to leave and could not go back to their homeland'. But today, it is more commonly used in a broader sense to refer to: 'Emigrants and their descendants, who live outside the country of their birth or ancestry, either on a temporary or permanent basis, yet still maintain affective and material ties to their countries of origin'. In emphasising 'affective and material ties', this conceptualisation reflects the influence of transnationalism. 


\section{The thematic section}

The thematic section of this edition of Melbourne Asia Review examines issues to do with transnationalism, diaspora and the migration-development nexus in Asia and Australia.

Asia has been central to the increased global movement of people that has occurred in recent decades. According to UN DESA, over 40 percent of people living outside their countries of origin in 2019 were born in Asia with India, China, Bangladesh, Pakistan, the Philippines, Afghanistan, Indonesia and Myanmar being the largest source countries. Many of these people live in other parts of Asia, especially Saudi Arabia and the United Arab Emirates, although large numbers live in Europe and North America. In addition, Asia has become home to millions of people from other parts of the world, especially from countries in Africa and Europe.

Australia has also played a part in the increased global movement of people, albeit a much smaller one. Immigration has accounted in large part for Australia's population doubling over the last 50 years. About half of the Australian population was either born overseas or had at least one parent born overseas. There has been a dramatic shift in the major source regions: from Europe and the UK before the mid-1990s, to Asia in the last two decades. Australia is also becoming a growing source of migrants to other countries, especially New Zealand and countries in Europe, North America, and Asia.

At the same time, both Asian countries and Australia are increasingly conceiving of and referring to their expatriates as diasporas. Moreover, states, diasporas and civil societies in these countries are forging a variety of transnational linkages that have had, or promise to have, a significant influence on development outcomes in origin and destination countries such as levels of trade, investment and economic competitiveness, livelihoods for poor people, and protection of migrant workers' rights. 
Issues of transnationalism and diaspora are consequently extremely pertinent in the Asian and Australian contexts.

Collectively, the papers in this thematic section reinforce and extend this view in two ways. On the one hand, they provide further evidence of transnational activity on the part of states, diasporas and civil societies that has implications for development outcomes in homelands and destination countries. On the other hand, they also show that the nature and purpose of transnational linkages are often contested, with important implications for the models of development pursued within the region.

Much transnational analysis-both on Asia and Australia and beyond-has focused on identifying the perceived benefits of transnational migration to origin and destination countries. It has often had an explicit policy focus and emphasised the potential role of diasporas as agents of development.

In contrast, these papers suggest that the development-related impacts of transnational linkages and diaspora in Asia and Australia cannot be taken for granted but rather are determined through processes of political and social struggle.

\section{The issues}

The specific issues covered in this thematic section cluster around five main concerns.

The first is the nature and politics of state diaspora engagement strategies. The papers by Yan Tan on China, Robi Rado on India, and Andrew Rosser on Australia show that states in these countries are engaging with their diasporas in various ways and that such engagement involves political choices with regards to models of development pursued; and is consequently subject to political or geopolitical contestation.

The second concern is the role of migrant or diasporic organisations in mediating 
relations between diasporas and homelands and, in so doing, shaping the claims that diasporas make, the activities in which they engage, and responses to their activities in origin and destination countries.

For instance, the paper by Annisa Amalia and colleagues on Indonesian diaspora organisations points to inequalities of wealth and power within the Indonesian diaspora-specifically between elite and professional elements, on the one hand, and low-wage migrant workers on the other-and the way these have shaped the claims these organisations make on behalf of the Indonesian diaspora and the role they play in Indonesian politics and society.

The third concern is the role of transnational civil society activist networks and international organisations in promoting the rights of subaltern elements such as migrant workers and victims of trafficking. Laura Foley and Nicola Piper's paper examines how transnational civil society organisations and trade unions supported by the International Labour Organization drove historic labour reforms in Qatar, a country with a large migrant workforce, much of which hails from South Asia. Likewise, in her piece on human trafficking in Southeast Asia, Guangyu Qiao-Franco notes that 'trafficked persons build solidarity among their colleagues and align with NGOs and international organisations to advocate for change in their countries of origin and destination.'

The fourth concern is the impact of remittances on economic development in homelands. Asia is home to several countries that receive large sums in remittances including India, Bangladesh, Indonesia, and the Philippines. Jeremaiah Opiniano's article on the latter case suggests that the developmental impact of remittances in homelands can vary significantly in different parts of these countries depending on a range of local economic and social factors including whether there are accessible financial institutions and a favourable investment and entrepreneurial climate.

The fifth, and final, concern is destination states' engagement with other countries' diasporas within their borders. The papers by Chao Shi on Chinese business 
migration to Australia, Hong Liu on the new Chinese diaspora in Singapore, and Lan Anh Hoang on Vietnamese migrants in Russia and the interview with Fazal Rizvi show, in different ways, that transnational migration both raises challenges of migrant integration into destination societies and presents opportunities for states in these countries to harness migrants' transnational connections for their economic benefit. Whether and how these challenges and opportunities are managed, however, depends on state policy and the politics that shape these.

\section{Looking forward}

The COVID-19 pandemic has significantly disrupted our globalised and fast-paced world to a significant halt, among other things challenging migration processes and development pathways. UN DESA estimates indicate that the pandemic may have reduced the growth in the number of international migrants by around two million between mid-2019 and mid-2020. Since the start of the pandemic, many migrants have returned to their countries of origin after losing their jobs and to escape virus outbreaks. Reports suggest that such processes have had significant impact on Asia and Australia specifically.

However, post-pandemic recovery is strongly linked to migration and mobility systems. In this context, issues of transnationalism and diaspora will remain a significant determinant of the migration-development nexus in the region in the future.

Authors: Professor Andrew Rosser and Associate Professor Yan Tan

Image: Korean Peninsula at Night (NASA, International Space Station, 2014). Credit: NASA/Flickr. 